\title{
Nephroprotective role of diosgenin in gentamicin-induced renal toxicity: biochemical, antioxidant, immunological and histopathological approach
}

\author{
Prachi Mishra ${ }^{1}$, Deepa Mandlik' S. Arulmozhi ${ }^{1 *}$ and Kakasaheb Mahadik²
}

\begin{abstract}
Background: Aminoglycoside antibiotics, gentamicin (GM) owns the utmost nephrotoxic potential than other antibiotics from the same category. To the other side, diosgenin (DG) showed the antioxidant and anti-inflammatory property.

Results: The present study was aimed to explore the nephroprotective effect of diosgenin on gentamicin-induced renal toxicity in Wistar rats. Wistar albino rats were divided into six groups $(n=6)$ : Normal control $(N C)$, Nephrotoxicity control (GM), DG (20 mg/kg), DG (40 mg/kg), DG (80 mg/kg), accordingly. After the treatment, the nephroprotective effects of DG were assessed by measuring serum levels of creatinine ( $\mathrm{Cr}$ ), blood urea nitrogen (BUN), total proteins (TP), albumin and urea levels. Urine volume, proteins, electrolyte levels, creatinine clearance were also evaluated in urine samples. Oxidative stress was evaluated through the measurement of antioxidant stress markers in the kidney tissue. Changes in body weight and kidney weight were also recorded along with a histopathological examination of kidney sections. For evaluation of inflammation, TNF-a and IL-1 $\beta$ levels were measured in the blood serum using ELISA kits. GM intoxication induced elevated serum creatinine, BUN, urea, albumin and TP levels, urine electrolytes levels, pro-inflammatory cytokines, antioxidant parameters which were found to be decreased significantly in a dosedependent manner in rat groups received DG which was also evidenced by the histological observations.
\end{abstract}

Conclusion: DG showed a significant nephroprotective effect in a dose-dependent manner by ameliorating the GM induced nephrotoxicity in Wistar rats.

Keywords: Diosgenin, Gentamicin, Nephrotoxicity, Oxidative stress, Inflammation, Cytokines

\footnotetext{
*Correspondence: pharmarul@gmail.com; arulmozhi.s@bharatividyapeeth.

edu

${ }^{1}$ Department of Pharmacology, Bharati Vidyapeeth (Deemed To Be

University), Poona College of Pharmacy, Pune, Maharashtra 411038 , India

Full list of author information is available at the end of the article
} 


\section{Background}

Environmental pollutants, chemicals and drugs such as antibiotics can drastically alter the anatomical and physiological functions of various organs such as kidney, heart, liver and intestine [1]. However, drugs such as antibiotics became the major implicating factor in acute kidney injury due to indigenous functions of the kidney to excrete them. This acute renal injury often leads to renal failure which in turn associated with other pathological manifestations such as sepsis, cardiovascular disorders and diabetes [2]. Gram-negative bacterial infections are commonly treated by aminoglycoside antibiotics. Nephrotoxicity is a common problem associated with these aminoglycoside antibiotics. More than twenty-five percent of patients who receives aminoglycosides antibiotics might face the problem of nephrotoxicity [3]. Though the nephrotoxicity caused by GM is more potent and dose-dependent than any other aminoglycoside antibiotic [4]. However, at the lowermost therapeutic dose, it is responsible for causing $10-15 \%$ cases of acute kidney failure [5-7]. The probable mechanism behind GM induced nephropathy because of its accretion in the kidney tubules, which would results into glomerular, vascular and tubular destruction $[8,9]$. The exact mechanism underlying the GM induced nephrotoxicity is not yet known [10]. Recent research work has recommended the involvement of oxidative stress in the mechanism of nephrotoxicity with diminution of antioxidant enzymes [11, 12]. Modifications in the serum creatinine levels were also observed in the GM induced nephrotoxicity with structural changes in the renal tubules like tubular edema and necrosis [13]. Adding to that, TNF- $\alpha$ (Proinflammatory cytokine) is also known to involve in the pathophysiology of GM induced nephrotoxicity [14]. Furthermore, GM administration to rats also improves the liberation of reactive oxidative species (ROS). These ROS have been suggested to play a significant role in cell death in various pathological disease conditions like a renal failure $[15,16]$.

Diosgenin, a steroidal sapogenin belonging to the family Dioscoreaceae (Fig. 1) mainly present in fenugreek, yams and Costus species in high amount. They are obtained from numerous herbal species such as Smilax menispermoidea, Costus speciosus, Trigonella foenum and many other Dioscorea species [17, 18]. DG is used as a major bioactive precursor molecule for the production of steroidal drugs in pharmaceutical companies [19]. In this regards, primarily over the past 20 years, extensive animal experimentation have been done to know the benefits and importance of DG as a leading phytoconstituents in several disease conditions like antioxidant, hypolipidemic, anti-inflammatory, hypoglycemic, anticancer, anti-proliferative, allergic diseases, skin ageing, neurodegenerative and menopause [20-23]. Kanchan et al. have reported the renoprotective role of DG in streptozotocininduced diabetic rats via restoration of antioxidant biomarkers in kidney tissue after the administration of DG [24]. Wang et al. have reported the role of diosgenin in the regulation of renal proximal tubular fibrosis induced by high glucose possibly through epithelial-to-mesenchymal transition signals pathway [25]. Therefore, nutraceutical, cosmetic and pharmaceutical industries have attracted significant devotion towards DG.

Gentamicin revealed significant, reversible acute kidney damage and causes nephrotoxicity alike to other nephrotoxic drugs in preclinical evaluation. Numerous research studies have mentioned that GM may produce renal damaging effect through the stimulation of oxidative stress and pro-inflammatory cytokine mediators. To the other side, different studies have stated the anti-inflammatory and antioxidant effects of DG in various animal models. However, hitherto none of the research literature has been available to establish the probable nephroprotective effect of DG on GM induced nephrotoxicity.

Therefore, the present study was aimed to explore the nephroprotective role DG on GM induced nephrotoxicity in experimental animals and its correlation with the pro-inflammatory mediators and oxidative stress in the kidney.

\section{Methods \\ Drugs and chemicals}

Diosgenin, Pyrogallol, Thiobarbituric acid, Trichloroacetic acid (20\%), 5, 5-dithio-bis-2-nitro benzoic acid, $\mathrm{O}$-dianisidine hydrochloride were obtained from Sigma Aldrich, USA. Creatinine, total protein, blood urea nitrogen and albumin assay kits were procured from Accurex Biomedical, Thane. ELYTE 2 kits were purchased from Micare, India for the colorimetric determination of serum sodium and potassium. Thiopental was procured from Merck specialities Pvt. Ltd, Mumbai. All other chemicals used were of analytical grade.

\section{Experimental animals}

Thirty healthy male Wistar albino rats (200-220 g) were purchased from National Institute of Biosciences, Pune. Animals were maintained under $12 \mathrm{~h}$ light/dark cycle at a constant temperature, with free access to water and food ad libitum. The experimental protocol was approved by the Institutional Animal Ethical Committee of the College. All the animals were acclimatized for a period of eight days before the start of experiments. 


\section{Acute toxicity study}

The acute toxicity study of DG was performed in compliance with OECD guidelines (OECD 425). DG at doses of $55 \mathrm{mg} / \mathrm{kg}, 175 \mathrm{mg} / \mathrm{kg}, 550 \mathrm{mg} / \mathrm{kg}, 1750 \mathrm{mg} / \mathrm{kg}$, and $2000 \mathrm{mg} / \mathrm{kg}$ body weight were administered orally to overnight fasted healthy female Swiss albino mice and continuously monitored for behavioral changes, restlessness, respiratory, salivation, tremors and diarrhoea or any signs of toxicity or mortality from 2 to $48 \mathrm{~h}$ and up to 14 days [26].

\section{Selection of DG dose}

The dose of DG was selected based on the literature survey [27, 28]. Furthermore, a pilot study was performed for selecting doses of DG at 20, 40, and $80 \mathrm{mg} /$ $\mathrm{kg}$ for its potential of nephroprotective activity.

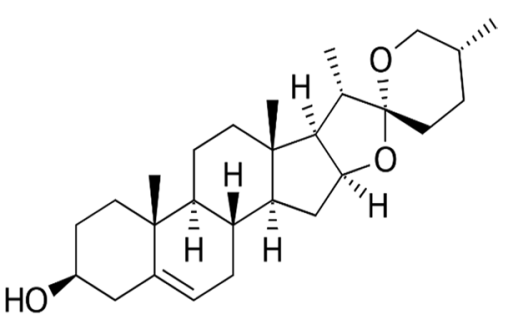

Fig. 1 Chemical structure of Diosgenin
Experimental induction of gentamicin induced nephrotoxicity

The rats were randomly divided into five groups of six rats $(n=6)$.

1. Normal Control (NC): Animals received saline orally for eight days.

2. Gentamicin (GM): Animals received GM (100 mg/ $\mathrm{kg})$, i.p., for eight days.

3. DG (20 mg/kg): Animals received DG $(20 \mathrm{mg} / \mathrm{kg}$ ) orally, after one hour received GM (100 mg/kg) i.p., for eight days.

4. DG $(40 \mathrm{mg} / \mathrm{kg})$ : Animals received DG $(40 \mathrm{mg} / \mathrm{kg})$ orally, after one hour received GM (100 mg/kg) i.p., for eight days.

5. DG $(80 \mathrm{mg} / \mathrm{kg})$ : Animals received DG $(80 \mathrm{mg} / \mathrm{kg})$ orally, after one hour received GM (100 mg/kg) i.p., for eight days.

On $9^{\text {th }}$ day rats were euthanized with thiopental (40 $\mathrm{mg} / \mathrm{kg}$, i. p.) to obtain blood samples for biochemical estimations and cytokines analysis. Kidneys were removed for histopathological analysis and measurement of antioxidant parameters. The blood samples were centrifuged at $3500 \mathrm{rpm}$ (15 min) for separation of serum. The separated serum samples were used for the analysis of renal markers such as $\mathrm{Cr}, \mathrm{TP}, \mathrm{BUN}$, albumin and cytokines (TNF- $\alpha$ and IL-1 $\beta$ ). Kidney and body weight

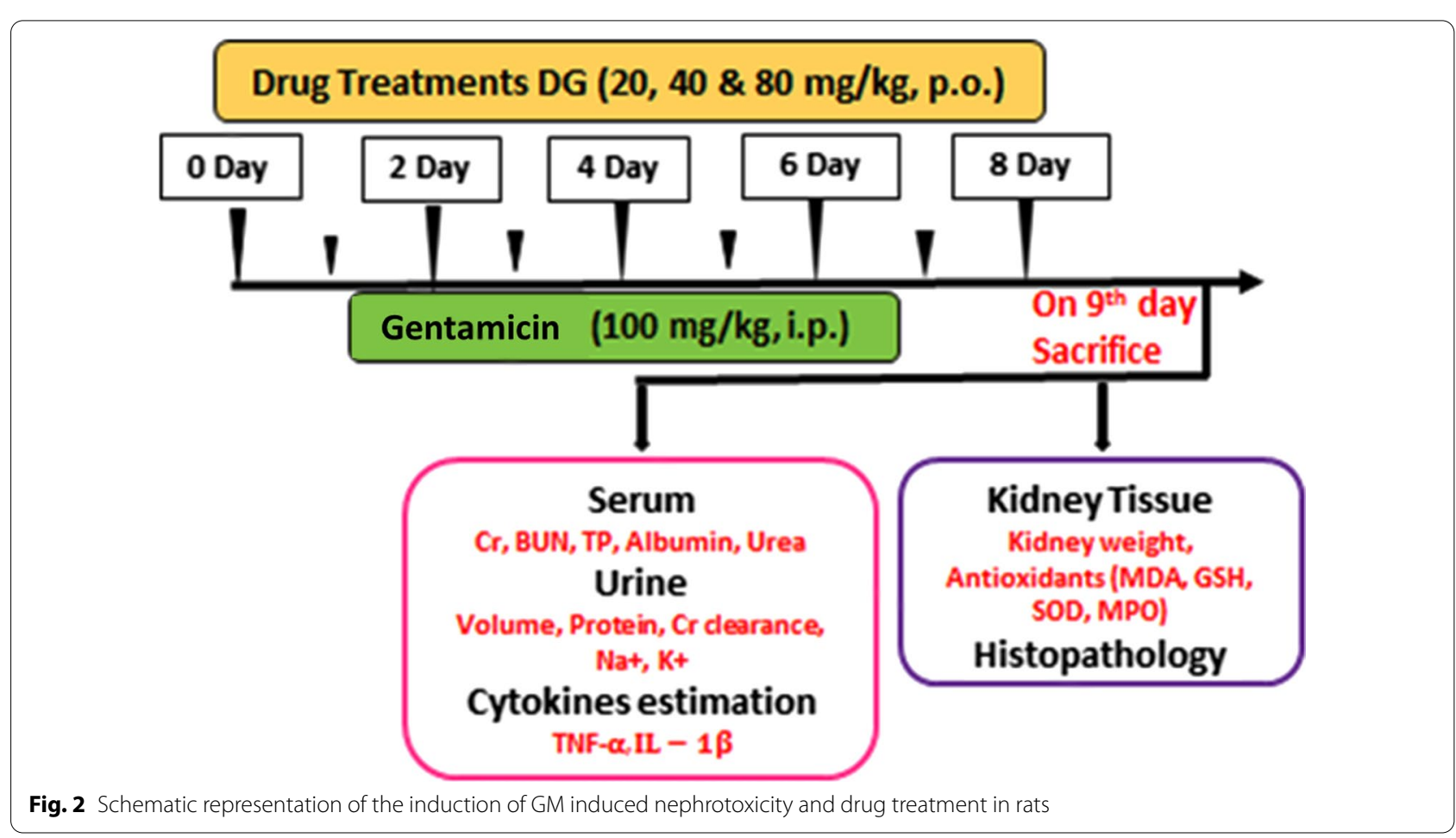


of rats were recorded after the experimental procedure. Urine samples were collected for $24 \mathrm{~h}$ in standard metabolic cages. During the period of urine collection, access to food was restricted but the water was offered ad libitum. The collected urine samples were used for the detection of urine volume, urine protein, creatinine clearance, urine sodium and potassium level. One part of the tissue was fixed in $10 \%$ formaldehyde for histopathological evaluation using haematoxylin and eosin ( $\mathrm{H} \& \mathrm{E})$ stain and the other part was used for measurement of oxidative stress markers like Malondialdehyde (MDA), Reduced Glutathione (GSH), Superoxide dismutase (SOD) and Myeloperoxidase (MPO) (Fig. 2) [29].

\section{Assessment of body weight and kidney weight}

On 9th day, the body weights were measured to evaluate the change in body weight. After the blood collection, the kidneys were excised, weighed and the result was expressed as wet kidney weight/100 g of body weight to assess the change in kidney weight [30].

\section{Assessment of serum biochemical parameters}

The estimation of serum Cr, TP, BUN, urea and albumin were carried out by using Accurex assay kits according to the manufacturer instructions.

\section{Assessment of urine biochemical parameters}

Urine was collected in polypropylene tubes and urine volume was measured. Urine samples were analyzed for protein, sodium, potassium, creatinine clearance using Accurex Biomedical kits, Thane and ELYTE 2 kits according to the manufacturer instructions.

\section{Assessment of oxidative stress markers}

Determination of MDA in the tissue was determined by the method of Ohkawa et al. [31]. The estimation of GSH was carried out by the method of Ellman, 1959 [32]. The determination of SOD was carried by Marklund and Marklund method, 1974 [33]. The estimation of MPO was done by the method of Barone et al. [34].

\section{Assessment of serum cytokine levels}

The estimation of TNF- $\alpha$ and IL- $1 \beta$ cytokines were carried out with ELISA kits, as per the manufacturer's protocol.

\section{Histopathological analysis}

The rat's kidneys were collected after sacrifice for histopathological examinations. The sections were cut at $4 \mu \mathrm{m}$ thick, fixed in $10 \%$ neutral buffered formalin and embedded in paraffin wax. Each section stained with hematoxylin and eosin stain to visualize cellular infiltration, tubular dilation, glomerular degeneration, vascular congestion and necrosis. The grading system used for assessment of parameters was (-: absence of damage; + : Up to $30 \%$ damage; $++: 30-70 \%$ damage; +++ : 70-100\% damage) [35].

\section{Statistical analysis}

Graph Pad Prism software was used for the statistical analysis of data. Results were expressed as mean \pm SEM. One Way Analysis of Variance (ANOVA) and post hoc Tukey's multiple comparison tests were used to analyze the data. A P-value of less than 0.05 was considered statistically significant.

\section{Results}

Effect of DG on assessment of body weight and kidney weight

The body weight of GM treated rats was found to be significantly $(p<0.001)$ decreased when compared with $\mathrm{NC}$ rats. However, the body weight were found to be improved significantly $(p<0.05 ; p<0.01 ; p<0.001)$ in DG + GM treated rats $(20,40$ and $80 \mathrm{mg} / \mathrm{kg}$ ) as compared to $\mathrm{GM}$ treated rats. Opposite to that, the kidney weight of GM treated rats was improved significantly $(\mathrm{p}<0.001)$ when compared to $\mathrm{NC}$ rats. On the other hand, kidney weight was improved significantly $(p<0.01 ; p<0.001)$ in DG + GM treated rats $(20,40$ and $80 \mathrm{mg} / \mathrm{kg})$ when compared to GM rats (Fig. 5).

\section{Effect of DG on assessment of serum biochemical parameters}

As shown in Fig. 3, the serum Cr, BUN and urea levels were improved significantly $(p<0.001)$ in GM rats when compared to NC rats. However, the serum $\mathrm{Cr}(p<0.05$; $p<0.001)$, BUN $(p<0.01 ; p<0.001)$ and urea $(p<0.01$; $p<0.001)$ level exhibited remarkable reduction in the $\mathrm{DG}+\mathrm{GM}$ treatment groups $(40$ and $80 \mathrm{mg} / \mathrm{kg}$ ). The rats treated with DG + GM $(20 \mathrm{mg} / \mathrm{kg})$ exhibited a non-significant decrease in serum $\mathrm{Cr}$ and urea levels when compared to GM treated rats. These reductions were found to be more significant $(p<0.001)$ in DG $+\mathrm{GM}(80 \mathrm{mg} /$ $\mathrm{kg}$ ) treatment groups as compared to GM treated rats (Fig. 3).

On the other hand, serum levels of TP and albumin were decreased considerably $(p<0.001)$ in GM rats as compared to NC groups rats. However, TP $(p<0.01$; $p<0.001)$ and albumin $(p<0.05 ; p<0.01 ; p<0.001)$ levels were found to be increased significantly in rats treated with DG + GM (20, 40 and $80 \mathrm{mg} / \mathrm{kg})$ when compared to $\mathrm{NC}$ rats. The rats treated with $\mathrm{DG}+\mathrm{GM}(20 \mathrm{mg} / \mathrm{kg})$ exhibited a non-significant increase in serum TP level as compared to GM treated rats. 


\section{Effect of DG on assessment of urine biochemical parameters}

As specified in Fig. 4, the urine volume, urine Protein and urine sodium levels in GM treated rats was improved considerably as compared to NC rats $(p<0.001)$. However, urine volume and TP levels were found to be decreased significantly $(p<0.01 ; p<0.001)$ in rats treated with DG + GM (20, 40 and $80 \mathrm{mg} / \mathrm{kg})$ when compared to $\mathrm{NC}$ rats.

The urine potassium and creatinine clearance level of GM rats was decreased extensively as compared with the NC rats $(p<0.001)$. To the other side, urine potassium and creatinine clearance level were improved significantly $(p<0.05 ; p<0.01 ; p<0.001)$ in DG + GM treated rats $(40$ and $80 \mathrm{mg} / \mathrm{kg}$ ) when compared with GM rats. However, there was a non-significant decrease in the urine potassium and creatinine clearance level in rats treated with $\mathrm{DG}+\mathrm{GM}$ (20 mg/kg) when compared to NC rats (Fig. 5).

\section{Effect of DG on assessment of oxidative stress markers}

As specified in Fig. 6, tissue MDA and MPO level of GM treated rats was increased significantly $(p<0.001)$ when compared with the $\mathrm{NC}$ rats. However, tissue MDA and MPO level were improved significantly $(p<0.01$; $p<0.001)$ in $\mathrm{DG}+\mathrm{GM}$ treatment rats $(40$ and $80 \mathrm{mg} /$ $\mathrm{kg}$ ) when compared with GM rats. However, there was a non-significant decrease in the tissue MPO level was found in DG $(20 \mathrm{mg} / \mathrm{kg})$ treated rats as compared to the $\mathrm{NC}$ group rats. On the other hand, tissue GSH and SOD level of GM rats was decreased significantly $(p<0.001)$ when compared with the NC rats. Tissue GSH and SOD level was improved significantly $(p<0.01 ; p<0.001)$ in DG + GM treatment rats (40 and $80 \mathrm{mg} / \mathrm{kg}$ ) when compared with GM rats. However, there was a non-significant increase in the tissue SOD level was found in rats treated with DG $(20 \mathrm{mg} / \mathrm{kg})$ when compared to NC rats.

\section{Effect of DG on assessment of pro-inflammatory markers}

The serum TNF- $\alpha$ and IL- $1 \beta$ level of GM treated rats were augmented significantly $(p<0.001)$ as compared to NC groups animals. Whereas, the rats treated with DG + GM treatment rats (40 and $80 \mathrm{mg} / \mathrm{kg}$ ) showed significant improvement in the serum TNF- $\alpha$ and IL-1 $\beta$ levels when compared to GM rats. However, there was a non-significant increase in the serum TNF- $\alpha$ and IL-1 $\beta$ level was found in rats treated with DG $(20 \mathrm{mg} / \mathrm{kg})$ when compared to NC rats (Fig. 7).

\section{Effect of DG on histopathological evaluation}

In kidney sections of NC rats, showed a normal renal glomeruli surrounded by capsule and normal proximal, distal and convoluted tubules (Fig. 8A). The kidney sections of GM treated rats on showed severe damage such as tubular epithelial cell necrosis, accumulation of inflammatory cells (neutrophils), tubular dilation, glomerular sclerosis, intertubular hemorrhage, cellular swelling and in certain areas haemorrhage was also seen (Fig. 8B). Mild histopathological lesions were observed in glomerulus and renal tubules of the kidney tissues of rats receiving different doses of DG (20, 40 and $80 \mathrm{mg} / \mathrm{kg}$ ). The tubular damage was less evident in the rats receiving 40 and $80 \mathrm{mg} / \mathrm{kg}$ of DG (Fig. $8 \mathrm{C}-\mathrm{E}$ ). Histological scoring in GM induced renal injury is shown in Table 1.

\section{Discussion}

Gram-negative bacterial infections are commonly treated by using aminoglycoside antibiotics like GM. There usage are restricted due to its severe side effects on the kidney. The nephrotoxic potential of the aminoglycosides antibiotic like GM is well documented [36]. Numerous research works have stated the involvement of oxidative stress through the generation of reactive oxygen species (ROS) in kidney injury [37]. Furthermore, these generated reactive oxygen species are also participated in GM induced renal tubular necrosis and acute renal failure [38]. Diverse mechanisms are involved in ROS (Superoxide anions and hydroxyl radicals) mediated GM nephrotoxicity that causes cell injury and cell death such as DNA damage, lipid peroxidation, inhibition of cellular respiration and creation of adenosine triphosphate, electron transport chain inhibition and destabilization of the tubular cell membrane. The renal morphological changes are altered due to deposition of GM in the renal cortex in which the disease condition is very alike to human beings and experimental animals. Therefore, GM induced nephrotoxicity experimental model was selected to study the molecular and pathological mechanism of kidney injury [38]. In recent times, more focus is thrown on herbs and herbal supplements in a variety of diseased conditions due to their minimal side effects. Therefore, the present study was aimed to evaluate the nephroprotective role of DG on GM induced nephrotoxicity. The current research work reveals that DG can improve GM prompted kidney tubular inflammation, oxidative stress, histopathological changes and instabilities of kidney function.

Enhancement in the serum levels of $\mathrm{Cr}, \mathrm{BUN}$, urea, proteins, albuminuria, decrease in glomerular filtration rate are the indications of GM mediated renal failure [39]. In our study, the GM treated rats showed abnormal serum BUN, urea, proteins, $\mathrm{Cr}$ and albumin levels. The treatment of rats with $20 \mathrm{mg} / \mathrm{kg}$ of DG with GM did not exhibit significant nephroprotective activity as shown by the raised levels of serum $\mathrm{Cr}$, urea and albumin respectively. Whereas rats treated with DG+GM (40 and $80 \mathrm{mg} / \mathrm{kg}$ ) doses confirmed diminution of the 

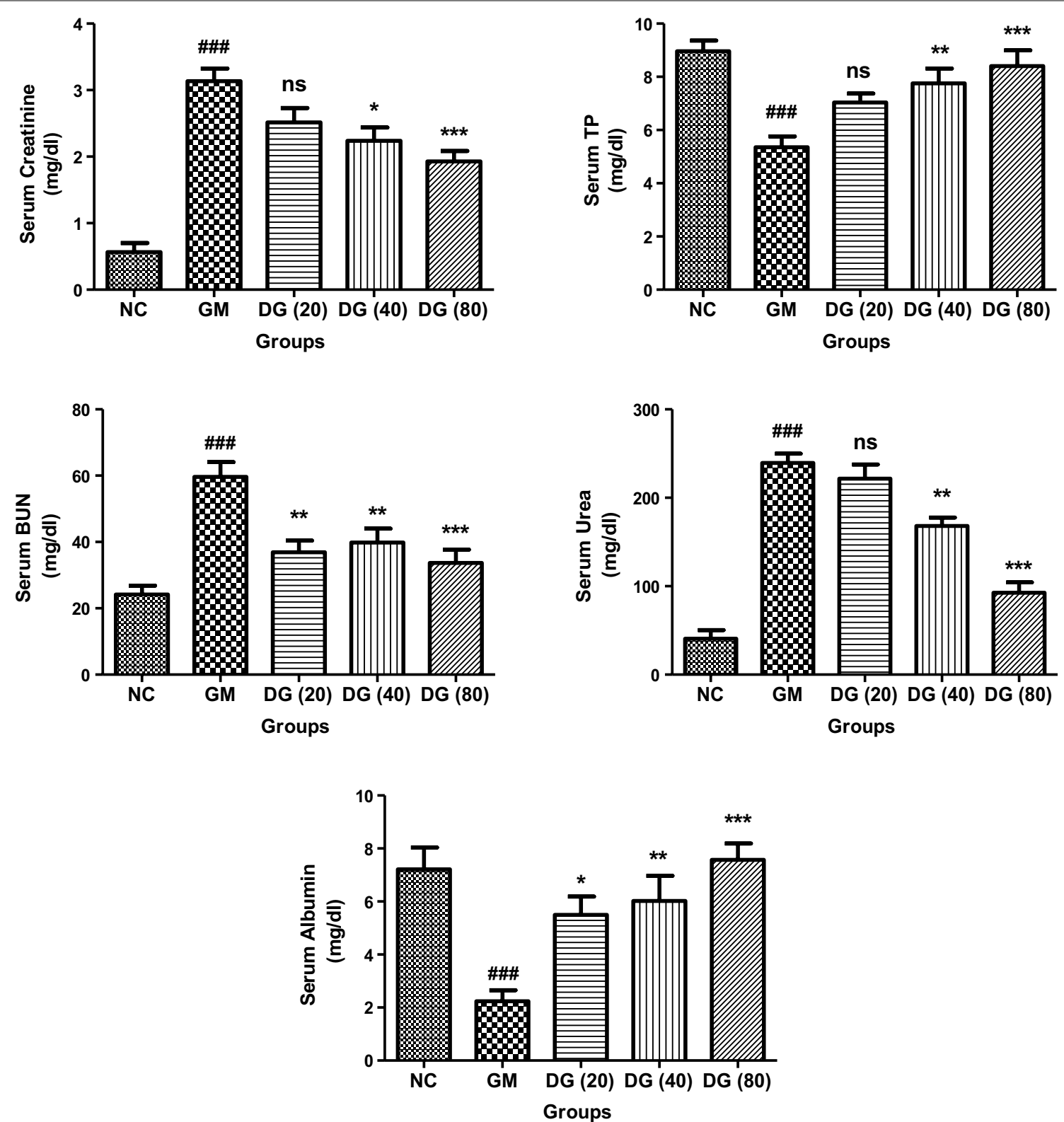

Fig. 3 Effect of DG on serum Cr, TP, BUN, urea and albumin (mg/dl) in GM induced renal damage in rats. Results are expressed as Mean $\pm S E M$ $(n=6) .{ }^{\# \#} p<0.001$ as compared to NC rats and ${ }^{*} p<0.05,{ }^{* * *} p<0.01,{ }^{* * *} p<0.001$ compared to GM rats

nephrotoxicity injury as demonstrated by declining serum and urine biomarkers. Furthermore, the nephroprotective potential of DG on clearance of creatinine might be credited to its antioxidant potential, as impaired glomerular filtration rate is linked to ROS [40]. Furthermore, the serum urea, uric acid and urinary protein level were elevated during renal injury [41] that may be a profound biomarker of kidney injury, reduced absorptive ability of tubule protein or diminished filtration of protein at glomerulus capsular barrier [42]. In this research, the levels of serum biomarkers like $\mathrm{Cr}$, urea and uric acid were elevated significantly on GM treatments to rats when compared to $\mathrm{NC}$ rats. The aminoglycosides nephrotoxicity would results in increased serum $\mathrm{Cr}$ and imbalances in serum electrolytes levels.

The concept behind the aminoglycoside nephrotoxicity is clinically significant as it results in azotemia conditions (an oliguric acute renal failure). Urinary output of GM treated rats for $24 \mathrm{~h}$ was significantly elevated as compared to $\mathrm{NC}$ rat indicating the polyuria conditions of 

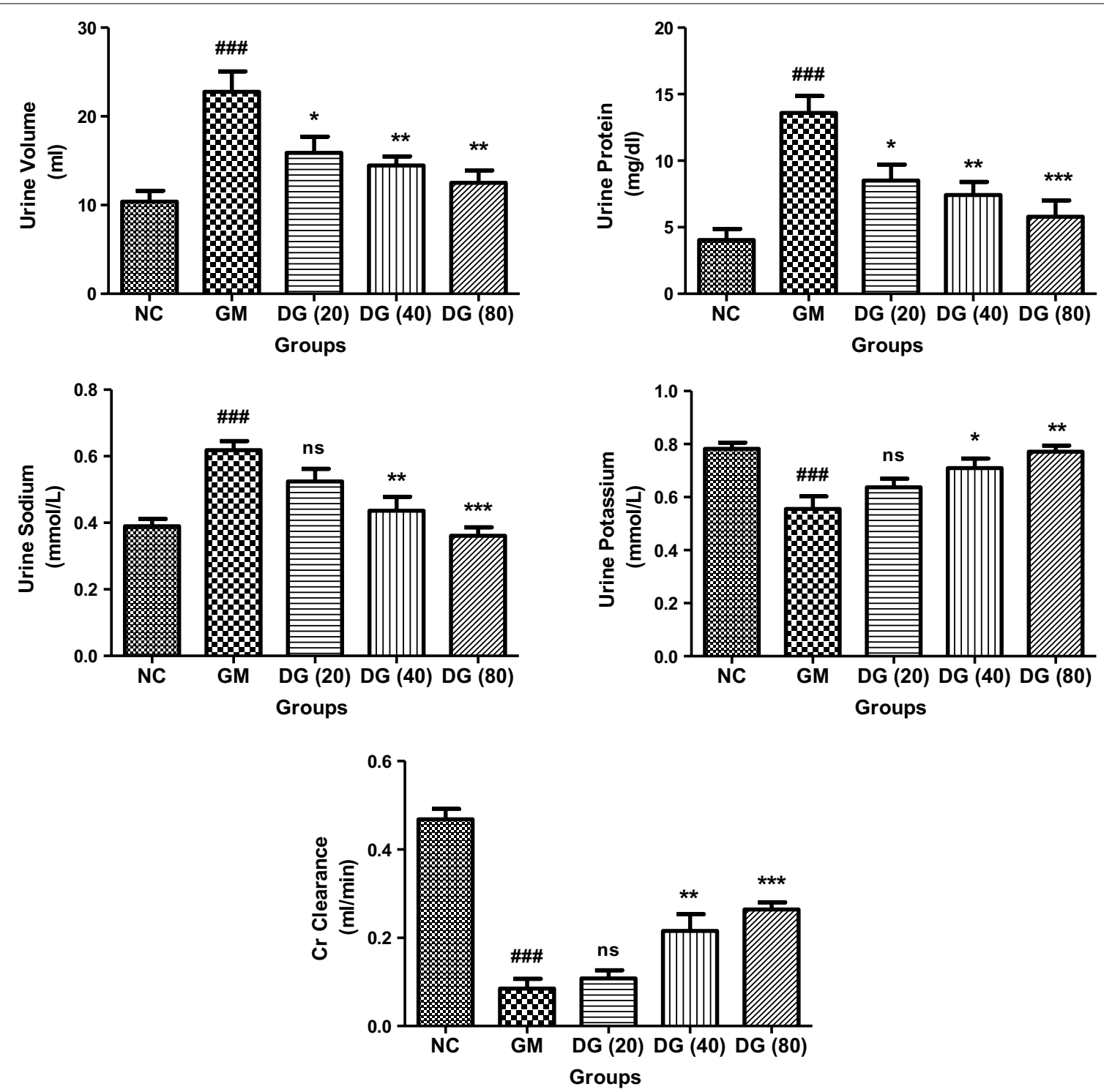

Fig. 4 Effect of DG on urine volume, urine Protein, urine Sodium, urine Potassium and creatinine clearance in GM induced renal damage in rats. Results are expressed as Mean \pm SEM $(n=6) .{ }^{\# \# \#} p<0.001$ as compared to NC rats and ${ }^{*} p<0.05,{ }^{* * *} p<0.01,{ }^{* * *} p<0.001$ compared to GM rats

rats. However, the rats receiving treatment of $\mathrm{DG}+\mathrm{GM}$ (20, 40 and $80 \mathrm{mg} / \mathrm{kg}$ ) urine volume was considerably decreased as compared to GM treated experimental animals, indicating the protective role of DG against acute tubular necrosis. In this study, intraperitoneal injection of GM for eight days resulted in a significant decline in body weight and elevation in kidney weight when matched with $\mathrm{NC}$ rats. This decline in the body weight may be associated with renal tubule damage results in the incapability of renal tubules to reabsorb water that both would result in dehydration and loss of body weight [43] or improved catabolism and reduced food ingestion
[44]. The rise in kidney weight after administration of GM injection was an outcome of tubular cells inflammation and edema [45]. The reduction in body weight and improvement in kidney weight were also proposed in the prior research $[46,47]$. The serum $\mathrm{K}^{+}$levels were decreased significantly in the GM treated rats as compared to NC rats. The observations were also seen in the previous work of Silan et al., 2007 and Said, 2011 in which the $\mathrm{K}^{+}$levels were also not found to be elevated in rats with GM induced nephrotoxicity $[48,49]$.

The functional integrity of kidney was evaluated by measuring the particular serum biomarker enzymes and 

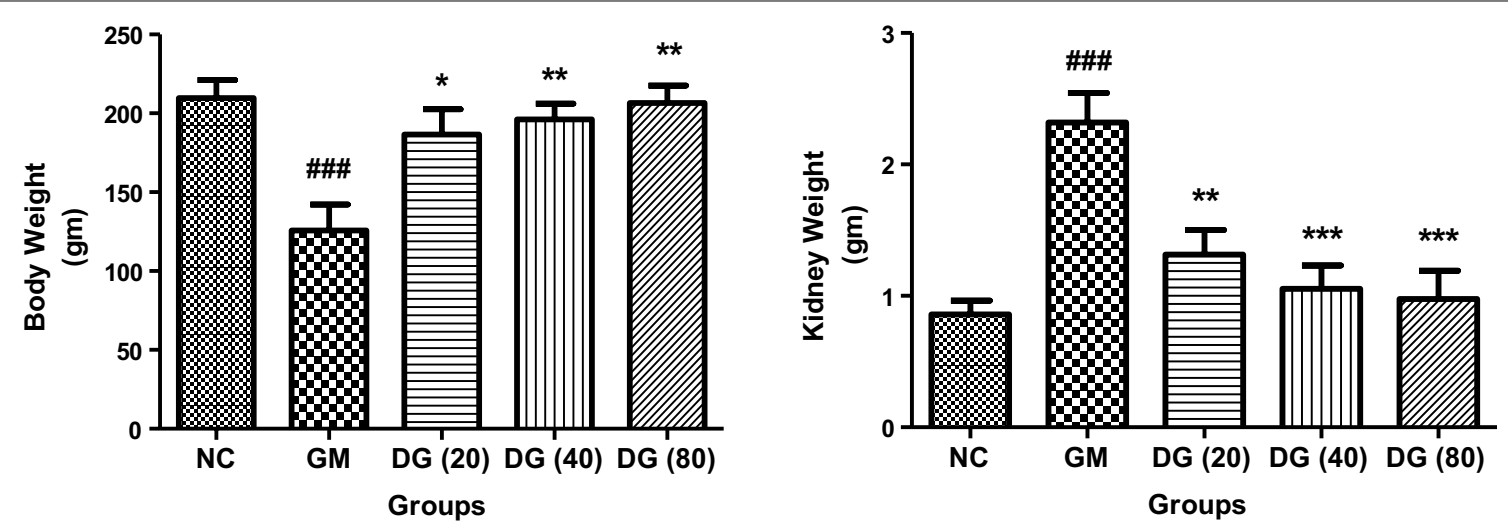

Fig. 5 Effect of DG on body weight and kidney weight (gm) in GM induced renal damage in rats. Values expressed as Mean $\pm S E M(n=6)$. $\# \#<0.001$ as compared to NC rats and ${ }^{*} p<0.05,{ }^{* *} p<0.01$ as compared to the GM group
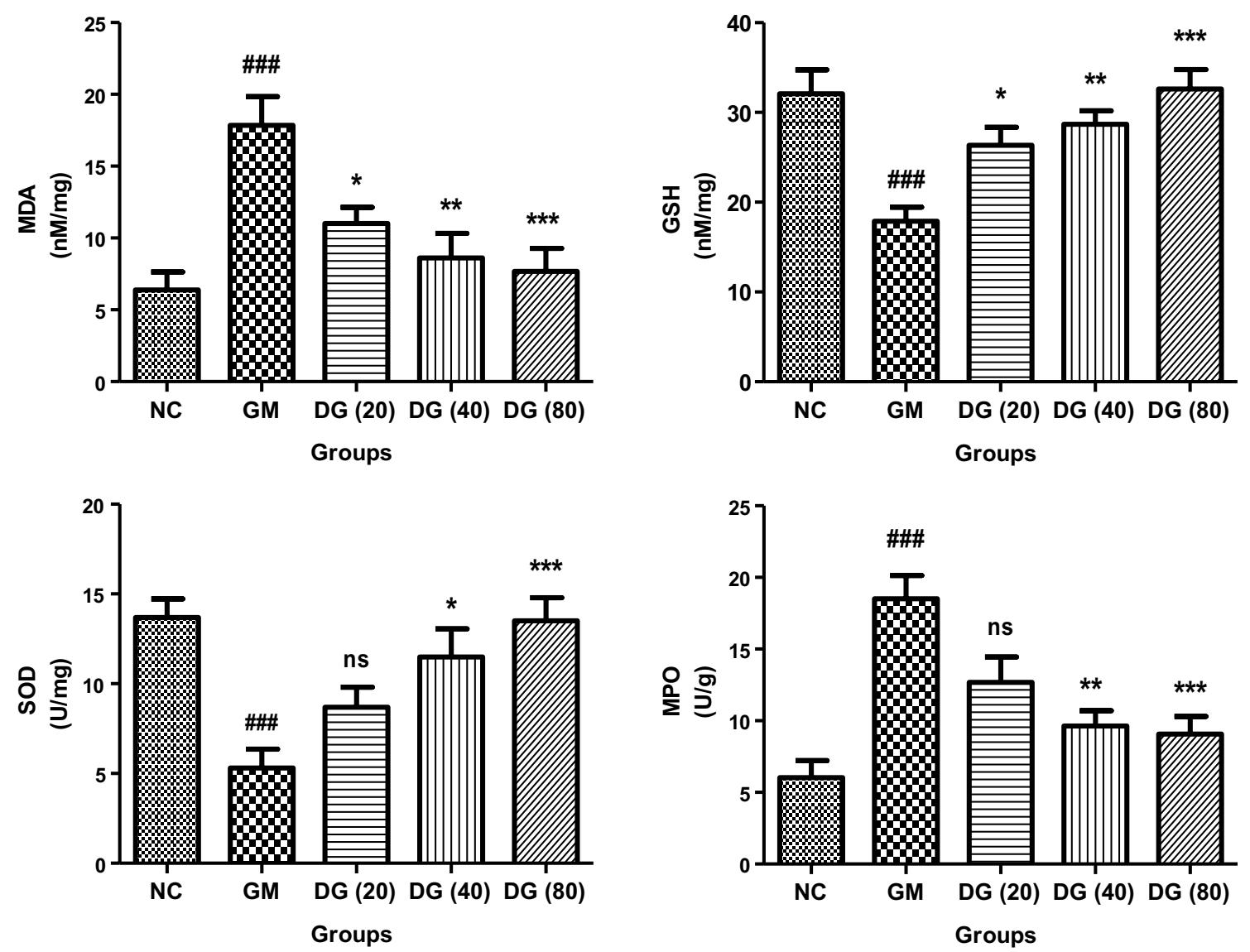

Fig. 6 Effect of DG on MDA, GSH, SOD and MPO levels in GM induced renal damage in rats. Values expressed as Mean \pm SEM $(n=6)$. ${ }^{\# \#} p<0.001$ as compared to $\mathrm{NC}$ rats and ${ }^{*} p<0.05,{ }^{* *} p<0.01,{ }^{* * *} p<0.001$ as compared to GM group

antioxidant stress markers as the brush border membrane and other cellular components (lysosomes and mitochondria) are the identified targets of gentamicin in nephrotoxicity $[50,51]$. In this study, we have accessed the levels of MDA, GSH, SOD and MPO as a result of GM induced oxidative stress. GM prompted nephrotoxicity is linked with a diminished potential of various antioxidant enzymes (CAT and SOD) in the kidney 

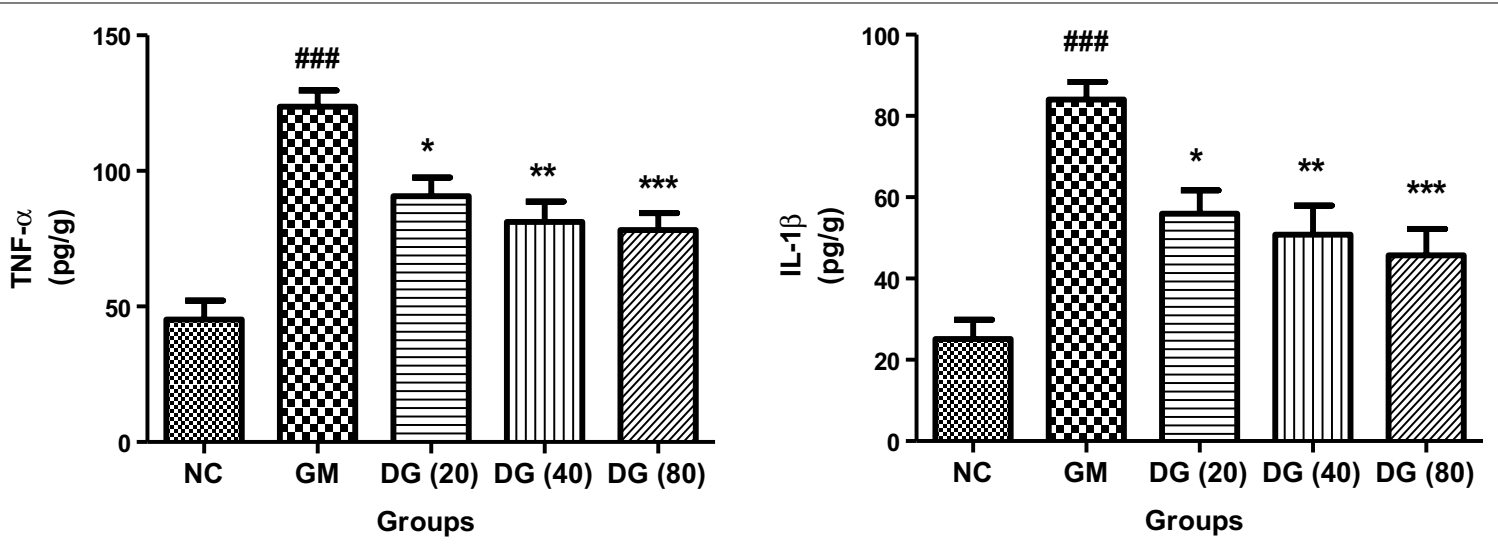

Fig. 7 Effect of DG on TNF- $a$ and IL-1 $\beta(p g / g)$ in GM induced renal damage in rats. Values expressed as Mean $\pm S E M(n=6) . \# \#<0.001$ as compared to NC rats and ${ }^{*} p<0.05,{ }^{* *} p<0.01,{ }^{* * *} p<0.001$ as compared to GM group

cortex region [52]. Moreover, these reduced levels of kidney antioxidant enzymatic system can magnify oxidative damage in rats [40].

Glutathione is a main intracellular reducing agent that causes detoxification of lipid peroxides and is associated with other antioxidants like $\mathrm{NADPH}$, vitamin $C$ and vitamin $E$, protecting against oxidative stress. GSH is a scavenger of hydroxyl radicals and singlet oxygen [53]. In association with SOD, that enhances the generation of oxygen and hydrogen peroxide from superoxide anion [54]. Enhancement in the MDA levels recommends improved oxidative stress in GM induced nephrotoxicity in the rat model [55]. In this study, the levels of MDA was found to be significantly improved whereas the levels of GSH, CAT and SOD were decreased in the rat kidney underwent GM treatment as compared to $\mathrm{NC}$ rats. In this experimental model, DG exhibits nephroprotective potential by increasing the activity of GSH, CAT and SOD enzymes and decreasing the level of MDA (lipid peroxidation marker) that finally would result in decreasing the oxidative stress. Here, the expressions of pro-inflammatory cytokines like TNF- $\alpha$ and IL- $1 \beta$ was found to be increased significantly. It is revealed that NF- $\mathrm{B}$ pathway displays a central part in the stimulation of proinflammatory cytokines subsequent GM treatment to rats. The binding of NF- $\mathrm{kB}$ to IкB (inhibitor protein) results in inactivation of NF- $\mathrm{kB}$ in normal cells.

The generation of ROS, on GM administration, resulted in the devastation of IкB and NF- $\mathrm{KB}$ release, that enters the nucleus and stimulates the transcription of inflammatory cytokines like TNF- $\alpha$ and IL-1 $\beta$ [56-58]. The generated TNF- $\alpha$ was responsible for disturbances in renal functions through decreased blood flow, vasoconstriction and gathering of leukocytes at the site of injury [56]. The serum levels of TNF- $\alpha$ and IL- $1 \beta$ were increased noticeably in the GM rats as compared to NC rats whereas, the rats treated with DG were found to be decreased levels of TNF- $\alpha$ and IL-1 $\beta$. Furthermore, DG reduced the TNF- $\alpha$ expression, a pro-inflammatory cytokine involved in inflammation as well as tissue remodelling that resulted in renal fibrosis [59].

Histopathological analysis signifying structural variations in renal tissue treated with aminoglycoside antibiotics like GM were stated by specific investigators [60, 61]. The histopathological analysis of kidney tissue displayed severe and extensive kidney destruction in rats receiving GM treatment along with renal tubule dilation and necrosis, glomerular sclerosis, cellular swelling and edema, which are in accordance to these reported studies. The possible reason behind such a kind of damage may be the generation of extremely reactive free radicals due to oxidative stress caused due to GM treatment to rats. The normal architecture of kidney histological features was restored in $\mathrm{NC}$ rats as compared to GM treated rats showing more widespread and noticeable renal tubule necrosis. Whereas, minor glomerular sclerosis and accumulation of inflammatory cells (neutrophils) were observed with normalization of kidney histological structure in rats treated with GM+DG. These results were also supported by previous similar studies on GM induced nephrotoxicity and its reversal by several drugs [62-64].

In summary, present study demonstrated the nephroprotective potential of DG on GM induced nephrotoxicity in rats. The precise mechanism behind nephroprotective activity of DG may be significant downregulation of serum and urinary biochemical parameters, kidney tissue homogenate oxidative stress 


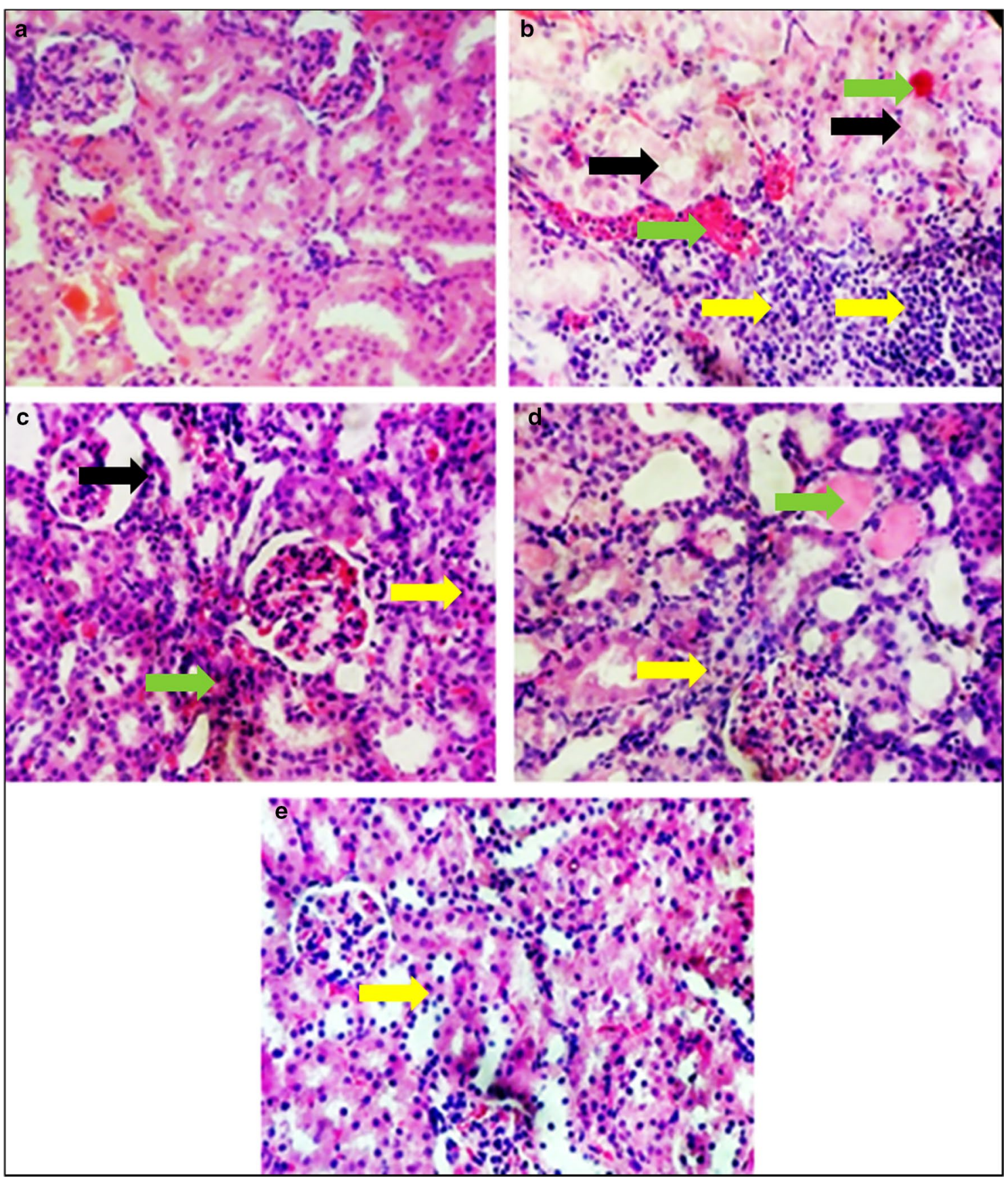

Fig. 8 Histopathological results of kidney sections stained with H \& E in GM induced renal damage in rats ( $\times 40)$. a NC; Group; b GM; c: DG (20); d: DG (40); DG (80). Black arrow indicates: Degeneration and necrosis in renal tubules; Yellow arrow indicates: inflammatory cells infiltration (neutrophils); Green arrow indicates: inter-tubular hemorrhage

markers, serum proinflammatory cytokines and reduction of severe and extensive kidney destruction in rats. Our findings support that DG represents a new therapy for GM-induced nephrotoxicity and may have a considerable impact on future clinical treatments of patients with renal failure; however, more investigation on levels of nitric oxide and molecular markers in the kidney homogenate [65] are limitations which are needed to determine the precise mechanism of action of DG. 
Table 1 Grading of histological features of kidney tissue sections in gentamicin-induced nephrotoxicity in rats

\begin{tabular}{lllll}
\hline Group & $\begin{array}{l}\text { Tubular } \\
\text { epithelial cell } \\
\text { necrosis }\end{array}$ & $\begin{array}{l}\text { Infiltration of } \\
\text { inflammatory } \\
\text { cells }\end{array}$ & $\begin{array}{l}\text { Tubular } \\
\text { dilation }\end{array}$ & $\begin{array}{l}\text { Glomerular } \\
\text { sclerosis }\end{array}$ \\
\hline NC & - & - & - & - \\
GM & +++ & ++++ & +++ & +++ \\
DG (20) & ++ & ++ & ++ & ++ \\
DG (40) & ++ & + & + & + \\
DG (80) & - & + & - & - \\
\hline
\end{tabular}

\section{Conclusion}

Gentamicin at a dose of $100 \mathrm{mg} / \mathrm{kg}$, i.p. causes significant kidney injury as supported by oxidative stress and histopathological damage in the kidney tissue. The probable mechanism behind GM induced nephrotoxicity may be a restoration of serum and urine biochemical parameters, reduction of oxidative stress and diminution of an inflammatory response by measuring the pro-inflammatory cytokines levels in serum. DG is a potent free radicals scavenging agent that gives protection against GM encouraged nephrotoxicity. Hence, the current research recognizes DG as a challenging nephroprotective drug against kidney damage. In this study, a dose of 40 and $80 \mathrm{mg} / \mathrm{kg}$ of DG was found to be more efficient than $20 \mathrm{mg} / \mathrm{kg}$, highlighting a dose-dependent role of DG on kidney GM induced renal injury.

\section{Abbreviations}

GM: Gentamicin; DG: Diosgenin; NC: Normal control; Cr: Creatinine; BUN: Blood urea nitrogen; TP: Total proteins; H \& E: Haematoxylin and eosin; MDA: Malondialdehyde; GSH: Reduced Glutathione; SOD: Superoxide dismutase; MPO: Myeloperoxidase; ANOVA: One Way Analysis of Variance; ROS: Reactive oxygen species.
}

\section{Acknowledgements}

We would like to thank you, Principal, Dr. A. P. Pawar, Bharati Vidyapeeth (Deemed to be University), Poona college of pharmacy for helpful article suggestions.

\section{Authors' contributions}

PM has performed the experimental parts. DM and AS was responsible for literature research and drafting of a manuscript. KM has critically revised the manuscript. All authors have read and approved the manuscript.

\section{Funding}

No funding received for this research work.

\section{Availability of data and materials}

All data and material are available upon request.

\section{Declarations}

\section{Ethics approval and consent to participate}

The experimental protocol was approved by the Institutional Animal Ethical Committee of Poona College of Pharmacy, Pune (Registration No. 1703/ PO/C/13/CPCSEA; IAEC protocol number CPCSEA/PCL/13/2014-15).
Consent for publication

Not applicable.

\section{Competing interests}

The authors declare no conflicts of interest.

\section{Author details}

${ }^{1}$ Department of Pharmacology, Bharati Vidyapeeth (Deemed To Be University), Poona College of Pharmacy, Pune, Maharashtra 411038, India. ${ }^{2}$ Department of Pharmaceutical Chemistry, Bharati Vidyapeeth (Deemed To Be University, Poona College of Pharmacy, Pune, Maharashtra 411038, India.

Received: 4 March 2021 Accepted: 8 August 2021

Published online: 26 August 2021

\section{References}

1. Hussain T, Gupta RK, Sweety K, Eswaran B, Vijayakumar M, Rao CV (2012) Nephroprotective activity of Solanum xanthocarpum fruit extract against gentamicin-induced nephrotoxicity and renal dysfunction in experimental rodents. Asian Pac J Trop Med 5(9):686-691

2. Ouédraogo M, Lamien-Sanou A, Ramdé N, Ouédraogo AS, Ouédraogo M, Zongo SP, Goumbri O, Duez P, Guissou PI (2013) Protective effect of Moringa oleifera leaves against gentamicin-induced nephrotoxicity in rabbits. Exp Toxicol Pathol 65(3):335-339

3. Lopez-Novoa JM, Quiros Y, Vicente L, Morales Al, Lopez-Hernandez FJ (2011) New insights into the mechanism of aminoglycoside nephrotoxicity: an integrative point of view. Kidney Int 79(1):33-45

4. Balakumar P, Rohilla A, Thangathirupathi A (2010) Gentamicin-induced nephrotoxicity: Do we have a promising therapeutic approach to blunt it? Pharmacol Res 62(3):179-186

5. Vijay KK, Naidu MUR, Anwar A, Shifow RKS (2000) Probucol protects against gentamicin-induced nephrotoxicity in rats. Ind J Pharmacol 32(2):108-113

6. Morales Al, Detaille D, Prieto M, Puente A, Briones E, Arévalo M, Leverve X, López-Novoa JM, El-Mir MY (2010) Metformin prevents experimental gentamicin-induced nephropathy by a mitochondria-dependent pathway. Kidney Int 77(10):861-869

7. Ramhariya R, Ganeshpurkar A, Ayachi C, Kanojia P, Bansal D, Dubey N (2015) Ameliorative effect of rutin on gentamicin-induced nephrotoxicity in murine model. Austin J Pharmacol Ther 3(1):1066-1070

8. Park JW, Bae EH, Kim IJ, Ma SK, Choi C, Lee J, Kim SW (2010) Renoprotective effects of paricalcitol on gentamicin-induced kidney injury in rats. Am J Physiol Ren Physiol 298(2):F301-F313

9. Rodrigues FA, Prata MM, Oliveira IC, Alves NT, Freitas RE, Monteiro HS, Silva JA, Vieira PC, Viana DA, Libório AB, Havt A (2014) Gingerol fraction from Zingiber officinale protects against gentamicin-induced nephrotoxicity. Antimicrob Agents Chemother 58(4):1872-1878

10. Bello SO, Chika A (2009) Dose-dependent amelioration of gentamicininduced nephrotoxicity in adult swiss albino rats by vitamin B-complexe a preliminary study. Trop J Pharm Res 8(2):111-116

11. Balakumar P, Chakkarwar VA, Kumar V, Jain A, Reddy J, Singh M (2008) Experimental models for nephropathy. J Renin Angiotensin Aldosterone Syst 9(4):189-195

12. Ozbek E (2012) Induction of oxidative stress in kidney. Int J Nephrol 2012:465897

13. Moreira MA, Nascimento MA, Bozzo TA, Cintra A, da Silva SM, Dalboni MA, Mouro MG, Higa EM (2014) Ascorbic acid reduces gentamicin-induced nephrotoxicity in rats through the control of reactive oxygen species. Clin Nutr 33(2):296-301

14. El-Kashef DH, El-Kenawi AE, Rahim MA, Suddek GM, Salem HA (2016) Agmatine improves renal function in gentamicin-induced nephrotoxicity in rats. Can J Physiol Pharmacol 94(3):278-286

15. Grune T, Sommerburg O, Petras T, Siems WG (1995) Postanoxic formation of aldehydic lipid peroxidation products in human renal tubular cells. Free Radic Biol Med 18(1):21-27

16. Baliga R, Ueda N, Walker PD, Shah SV (1999) Oxidant mechanisms in toxic acute renal failure. Drug Metab Rev 31(4):971-977 
17. Chen PS, Shih YW, Huang HC, Cheng HW (2011) Diosgenin, a steroidal saponin, inhibits migration and invasion of human prostate cancer $\mathrm{PC}-3$ cells by reducing matrix metalloproteinases expression. PLoS ONE 6(5):e20164

18. Patel K, Gadewar M, Tahilyani V, Patel DK (2013) A review on pharmacological and analytical aspects of diosmetin: a concise report. Chin J Integr Med 19(10):792-800

19. Chen Y, Tang YM, Yu SL, Han YW, Kou JP, Liu BL, Yu BY (2015) Advances in the pharmacological activities and mechanisms of diosgenin. Chin J Nat Med 13(8):578-587

20. Corbiere C, Liagre B, Bianchi A, Bordji K, Dauça M, Netter P, Beneytout JL (2003) Different contribution of apoptosis to the antiproliferative effects of diosgenin and other plant steroids, hecogenin and tigogenin, on human 1547 osteosarcoma cells. Int J Oncol 22(4):899-905

21. Raju J, Mehta R (2008) Cancer chemopreventive and therapeutic effects of diosgenin, a food saponin. Nutr Cancer 61(1):27-35

22. Yue L, Chen L, Kou JP (2010) Recent advances of diosgenin in its pharmacological activities and mechanism. Chin J Clin Pharmacol Ther 15:233

23. Jesus M, Martins AP, Gallardo E, Silvestre S (2016) Diosgenin: recent highlights on pharmacology and analytical methodology. J Anal Methods Chem 2016:4156293

24. Kanchan DM, Somani GS, Peshattiwar V, Kaikini AA, Sathaye S (2016) Renoprotective effect of diosgenin in streptozotocin induced diabetic rats. Pharmacol Rep 68(2):370-377

25. Wang WC, Liu SF, Chang WT, Shiue YL, Hsieh PF, Hung TJ, Chen MF, Yang $Y L$ (2014) The effects of diosgenin in the regulation of renal proximal tubular fibrosis. Exp Cell Res 323(2):255-262

26. Organisation for Economic Co-operation and Development. Guidance document on acute oral toxicity testing Series on testing and assessment No. 24. Paris: OECD Environment, health and safety publications, 2001; www.oecd.org/ehs. Accessed 12 May 2008

27. Zhao WX, Wang PF, Song HG, Sun N (2017) Diosgenin attenuates neuropathic pain in a rat model of chronic constriction injury. Mol Med Rep 16(2):1559-1564

28. Chen J, Zhang H, Xiong C, Ruan JL (2016) Inhibitory effect of diosgenin on experimentally induced benign prostatic hyperplasia in rats. J Huazhong U Sci Tech [Med Sci] 36(6):806-810

29. Sodimbaku V, Pujari L, Mullangi R, Marri S (2016) Carrot (Daucus caroto L.): Nephroprotective against gentamicin-induced nephrotoxicity in rats. Indian J Pharmacol 48(2):122-127

30. Feyissa T, Asres K, Engidawork E (2013) Renoprotective effects of the crude extract and solvent fractions of the leaves of Euclea divinorum Hierns against gentamicin-induced nephrotoxicity in rats. J Ethnopharmacol 145(3):758-766

31. Ohkawa H, Ohishi N, Yagi K (1979) Assay for lipid peroxides in animal tissues by the thiobarbituric acid reaction. Anal Biochem 95(2):351-358

32. Ellman GL (1959) Tissue sulfhydryl groups. Arch Biochem Biophys 82(1):70-77

33. Marklund S, Marklund G (1974) Involvement of the superoxide anion radical in the autoxidation of pyrogallol and a convenient assay for superoxide dismutase. Eur J Biochem 47(3):469-474

34. Barone FC, Hillegass LM, Price WJ, White RF, Lee EV, Feuerstein GZ, Sarau HM, Clark RK, Griswold DE (1991) Polymorphonuclear leukocyte infiltration into cerebral focal ischemic tissue: myeloperoxidase activity assay and histologic verification. J Neurosci Res 29(3):336-345

35. Solez K, Morel-Maroger L, Sraer JD (1979) The morphology of acute tubular necrosis in man: analysis of 57 renal biopsies and a comparasion with the glycerol model. Med 58:362-366

36. Ali BH, Al Zaabi M, Blunden G, Nemmar A (2011) Experimental gentamicin nephrotoxicity and agents that modify it: a mini-review of recent research. Basic Clin Pharmacol Toxicol 109(4):225-232

37. Singh AP, Junemann A, Muthuraman A, Jaggi AS, Singh N, Grover K, Dhawan R (2012) Animal models of acute renal failure. Pharmacol Rep 64(1):31-44

38. Martinez-Salgado C, Eleno N, Morales Al, Pérez-Barriocanal F, Arevalo M, López-Novoa JM (2004) Gentamicin treatment induces simultaneous mesangial proliferation and apoptosis in rats. Kidney Int 65(6):2161-2171
39. Janjua A, Waheed A, Bakhtiar S (2014) Protective effect of metformin against gentamicin induced nephrotoxicity in rabbits. Pak J Pharm Sci 27(6):1863-1872

40. Abdel-Raheem IT, Abdel-Ghany AA, Mohamed GA (2009) Protective effect of Quercetin against gentamicin-induced nephrotoxicity in rats. Biol Pharm Bull 32(1):61-67

41. Perrone RD, Madias NE, Levey AS (1992) Serum creatinine as an index of renal function: new insights into old concepts. Clin Chem 38(10):1933-1953

42. Mueller PW, Lash LH, Price RG, Stolte H, Gelpi E, MaackT, Berndt WO (1997) Urinary biomarkers to detect significant effects of environmental and occupational exposure to nephrotoxins. I. Categories of tests for detecting effects of nephrotoxins. Ren Fail 19(4):505-521

43. Ali BH, Al-Qarawi AA, Haroun EM, Mousa HM (2003) The effect of treatment with gum Arabic on gentamicin nephrotoxicity in rats: a preliminary study. Ren Fail 25(1):15-20

44. Ali BH, Abdel Gayoum AA, Bashir AA (1992) Gentamicin nephrotoxicity in rat: some biochemical correlates. Pharmacol Toxicol 70(6):419-423

45. Erdem A, Gundogan NU, Usubutun A, Kılınc K, Remzi Erdem S, Kara A, Bozkurt A (2000) The protective effect of taurine against gentamicininduced acute tubular necrosis in rats. Nephrol Dial Transplant 15(8):1175-1182

46. Nasri H, Nematbakhsh M, Ghobadi S, Ansari R, Shahinfard N, Rafieiankopaei M (2013) Preventive and curative effects of ginger extract against histopathologic changes of gentamicin-induced tubular toxicity in rats. Int J Prev Med 4(3):316-321

47. El-Kashef DH, El-Kenawi AE, Rahim MA, Suddek GM, Salem HA (2016) Agmatine improves renal function in gentamicin induced nephrotoxicity in rats. Can J Physiol Pharmacol 94(3):278-286

48. Silan C, Uzun O, Comunoglu NU, Gokçen S, Bedirhan S, Cengiz M (2007) Gentamicin-induced nephrotoxicity in rats ameliorated and healing effects of resveratrol. Biol Pharm Bull 30(1):79-83

49. Said MM (2011) The protective effect of eugenol against gentamicin induced nephrotoxicity and oxidative damage in rat kidney. Fundam Clin Pharmacol 25(6):708-716

50. Farooq N, Priyamvada S, Khan F, Yusufi AN (2007) Time dependent effect of gentamicin on enzymes of carbohydrate metabolism and terminal digestion in rat intestine. Hum Exp Toxicol 26(7):587-593

51. Banday AA, Farooq N, Priyamvada S, Yusufi AN, Khan F (2008) Time dependent effects of gentamicin on the enzymes of carbohydrate metabolism, brush border membrane and oxidative stress in rat kidney tissues. Life Sci 82(9-10):450-459

52. Al-Yahya MA, Mothana RA, Al-Said MS, Al-Dosar M, Al-Sohaiban M, Parvez MK, Rafatullah S (2015) Protective effect of Citrus medica 'OTROJ' extract on gentamicin induced nephrotoxicity and oxidative damage in rat kidney. Dig J Nanomater Biostructures 10(1):19-29

53. Ghezzi P (2011) Role of glutathione in immunity and inflammation in the lung. Int J Gen Med 4:105-113

54. Larkin EK, Gao YT, Gebretsadik T, Hartman TJ, Wu P, Wen W, Yang G, Bai C, Jin M, Roberts LJ, Gross M, Shu XO, Hartert TV (2015) New risk factors for adult-onset incident asthma. A nested case-control study of host antioxidant defense. Am J Respir Crit Care Med 191(1):45-53

55. Humes HD, Weinberg JM (1986) Toxic nephropathies. In: Brenner BM, Rector FC (eds) The kidney. WB Saunders Co, Philadelphia, p 1491

56. Donnahoo KK, Shames BD, Harken AH, Meldrum DR (1999) Review article: the role of tumor necrosis factor in renal ischemia-reperfusion injury. Urol 162(1):196-203

57. Jaikumkao K, Pongchaidecha A, Thongnak LO, Wanchai K, Arjinajarn P, Chatsudthipong V, Chattipakorn N, Lungkaphin A (2016) Amelioration of renal inflammation, endoplasmic reticulum stress and apoptosis underlies the protective effect of low dosage of atorvastatin in gentamicininduced nephrotoxicity. PLoS ONE 11(10):e0164528

58. Ansari MA, Raish M, Ahmad A, Ahmad SF, Mudassar S, Mohsin K, Shakeel F, Korashy HM, Bakheet SA (2016) Sinapic acid mitigates gentamicininduced nephrotoxicity and associated oxidative/ nitrosative stress, apoptosis, and inflammation in rats. Life Sci 165:1-8 
59. Villegas I, Martín AR, Toma W, de la Lastra CA (2004) Rosiglitazone, an agonist of peroxisome proliferator-activated receptor $\mathrm{c}$, protects against gastric ischemia-reperfusion damage in rats: role of oxygen free radicals generation. Eur J Pharmacol 505(1-3):195-203

60. Polat A, Parlakpinar H, Tasdemir S, Colak C, Vardi N, Ucar M, Emre MH, Acet A (2006) Protective role of aminoguanidine on gentamicin- induced acute renal failure in rats. Acta Histochem 108(5):365-371

61. Sayed-Ahmed MM, Nagi N (2007) Thymoquinone supplementation prevents the development of gentamicin-induced acute renal toxicity in rats. Clin Exp Pharmacol Physiol 34:399-405

62. Nakakuki M, Yamasaki F, Shinkawa T, Kudo M, Watanabe M, Mizota M (1996) Protective effect of human ulinastatin against gentamicin-induced acute renal failure in rats. Can J Phys Pharmacol 74(1):104-111

63. Kumar KV, Shifow AA, Naidu MU, Ratnakar KS (2000) Carvedilol: a beta blocker with antioxidant property protects against gentamicin induced nephrotoxicity in rats. Life Sci 66(26):2603-2611
64. Karadeniz A, Yildirim A, Simsek N, Kalkan Y, Celebi F (2008) Spirulina platensis protects against gentamicin-induced nephrotoxicity in rats. Phytother Res 22(11):1506-1510

65. Fujihara CK, Sena CR, Malheiros DM, Mattar AL, Zatz R (2006) Short-term nitric oxide inhibition induces progressive nephropathy after regression of initial renal injury. Am J Physiol Renal Physiol 290:632-640

\section{Publisher's Note}

Springer Nature remains neutral with regard to jurisdictional claims in published maps and institutional affiliations.

\section{Submit your manuscript to a SpringerOpen ${ }^{\circ}$ journal and benefit from:}

- Convenient online submission

- Rigorous peer review

- Open access: articles freely available online

- High visibility within the field

- Retaining the copyright to your article

Submit your next manuscript at $\boldsymbol{\nabla}$ springeropen.com 